\title{
MITOLOGÍA PARA NIÑOS: EL RELATO FABULOSO GRECOLATINO SEGÚN FERNÁN CABALLERO
}

\author{
ANGÉLICA García-MANSO \\ Universidad de Extremadura \\ angmanso@unex.es
}

\section{RESUMEN}

Fernán Caballero escribe su Mitología contada a los niños a partir de los presupuestos mitográficos del siglo XIX, los cuales superan su función para entender la Literatura y el Arte previos y adquieren autosuficiencia como conocimiento escolar. La idea de fábula aplicada a los mitos supone convertir los relatos en cuentos para niños, con una doble lectura: de un lado, evemerista y, de otro, moral. Se analiza el empleo del término «fábula» en la obra según se aplica a dioses, héroes o personajes históricos. Concluimos, finalmente, que el texto transforma su sentido didáctico y de divulgación en una obra que puede inscribirse en la categoría de Literatura Infantil y Juvenil.

PALABRAS ClAVE: Fernán Caballero; mitología; cuentos; sentido didáctico; LIJ.

\section{ABSTRACT}

Fernán Caballero writes his Mitología contada a los niños from nineteenth century mythographical estimates, which exceed their function to understand previous Literature and Art, and they acquire self-sufficiency as scholar knowledge. The idea of fable applied to myths supposes to convert stories in tales for children, with a double reading: on the one hand, evemerist and, on the other hand, moral. The use of the term «fable» is analysed in the work as applied to gods, heroes or historical figures. It is concluded that the text transforms its educational sense into a work that can enrol in the category of Children's Literature.

KeYwords: Fernán Caballero; mythology; tales; educational sense; Children's Literature. 


\section{INTRODUCCIÓN Y ESTADO DE LA CUESTIÓN}

El siglo XIX es, entre otros muchos aspectos, también el siglo de la divulgación de la Mitología Clásica o, en otras palabras, de la «mitología divulgativa». El movimiento ilustrado había traído consigo que esa omnipresencia y omnipotencia de la percepción cristiana del mundo - tan arraigada en España - comenzara a perder peso paulatinamente y que se diera cabida a una circulación más generalizada de textos relacionados con la Mitología Clásica ${ }^{1}$. En un principio sería Francia el origen de la expansión de este nuevo acercamiento a la mitología, para, desde el primer tercio del siglo XIX, constituirse las universidades y editoriales alemanas en el punto de difusión de una mitología más moderna, con una índole ya filológica. En verdad, el panteón grecolatino y los relatos literarios han sido conocidos en todo momento en Europa, pero como soporte estético para la literatura y las artes, no como un saber autónomo, que podía rivalizar con los contenidos ideológicos del cristianismo². El concepto que lo engloba puede ser el de «teatro» (de hecho, uno de los textos de mayor trascendencia es el Teatro de los dioses de la Gentilidad, de Baltasar de Vitoria, publicado en $1646^{3}$ y cuyos volúmenes son reeditados también en el siglo XVIII $)$ y la disciplina de las «Instituciones poéticas» (como las publicadas por Santos Díez González en 1793, Instituciones poéticas, con un discurso preliminar en defensa de la poesía y un compendio de la historia poética o mitología, para inteligencia de los poetas ${ }^{5}$ ) o la de la «Poética» propiamente dicha (tal como aparece reflejada en el diccionario del francés Pierre Chompré, originalmente editado en 1727 y traducido en 1783: Diccionario abreviado de la fábula, para la inteligencia de los poetas, pinturas y estatuas, cuyos asuntos están tomados de la historia poética, en cuyo título aparece el término fábula, importante para nuestras próximas reflexiones $\left.{ }^{6}\right)$.

Solamente en la nueva realidad cultural ilustrada se entiende que en 1823 el liberal José de Urcullu publique un Catecismo de Mitología ${ }^{7}$, con la palabra «catecismo» con un sentido ecdótico que rivaliza con la acepción religiosa del término. Una nota en la misma portada del

${ }^{1}$ Los repertorios bibliográficos más importantes a este respecto en el siglo XIX son: Closa Farrés, Josep (1983): «Humanisme Classicista i Humanisme Cristià en l'ensenyament de la mitología al llarg dels segles XVIII i XIX hispànics», Faventia, 5, 131-139; Navarrete Orcera, Antonio Ramón (2002): «Manuales de Mitología en España (1507-2002)», Tempus. Revista de actualización científica sobre el mundo clásico en España, 31, 5-107, y González González, Marta (2013): «Aproximaciones al estudio de la Mitología en la España del XVIII y comienzos del XIX», García Jurado, Francisco, González Delgado, Ramiro y González González, Marta (Eds.) (2013): La historia de la literatura grecolatina en España: de la Ilustración al Liberalismo (1778-1850), Málaga: Analecta Malacitana / Universidad de Málaga, 211-223.

${ }^{2}$ Con amplia difusión en los distintos géneros literarios. Cf. Dumas, Claude (1988): Les mythes et leur expression au XIX siècle dans le monde hispanique et ibéro-américain, Lille, Presses Universitaires.

${ }^{3}$ De Vitoria, Baltasar (1646): Teatro de los dioses de la Gentilidad, Valencia, Garriz.

${ }^{4}$ Analizado en Calonge García, Genoveva (1992): «El Teatro de los Dioses de la Gentilidad y sus fuentes: Bartolomé Cassaneo», Cuadernos de Filología Clásica, Estudios Latinos, 3, 159-170; y Serés, Guillermo (2003): «El enciclopedismo mitológico de Baltasar de Vitoria», La Perinola, 7, 397-417.

5 Díez González, Santos (1793): Instituciones poéticas, con un discurso preliminar en defensa de la poesía y un compendio de la historia poética o mitología, para inteligencia de los poetas, Madrid, Benito Cano.

${ }^{6}$ Chompré, Pierre (1783): Diccionario abreviado de la fábula, para la inteligencia de los Poetas, Pinturas y Estatuas, cuyos asuntos están tomados de la Historia Poética, Madrid, Manuel de Sancha.

7 De Urcullu, José (1823): Catecismo de Mitología, Londres, Ackerman. 
volumen explicita el sentido con el que se emplea dicha palabra «catecismo» en la obra. En verdad, el volumen aparece editado en Londres y no en España, pero la obra circula hasta el punto de precisar una nueva edición dos años después.

La misma alusión a catecismo en el título de la obra de Urcullu aporta a la nueva mitología una clave pedagógica que impregnará en buena medida las publicaciones de manuales en España a lo largo del siglo XIX: la mitología como objeto de enseñanza y, sobre todo, de conocimiento de argumentos del pasado desde perspectivas eminentemente románticas, implicadas estéticamente con el objeto de estudio. De ahí también denominaciones como «compendio»y «elementos», que destacan el predominio de su uso didáctico ${ }^{8}$.

El siglo XIX se cierra con la publicación por parte de la conocida Editorial Calleja en su «Biblioteca enciclopédica para niños» ${ }^{9}$ de una Historia de la Mitología Griega y Romana de V. González ${ }^{10}$, aparecida en 1885, un manual en el que la ilustración es marca de la casa (por parte de los ilustradores Manuel Ángel y Narciso Méndez) con elaboradas estampas y, sobre todo, con carácter divulgativo, que anuncia nuevos enfoques a las puertas del siglo XX. Se trata de enfoques más narrativos, o, por así decir, más centrados en cada relato por encima de la idea de totalidad, la disposición alfabética o de los ámbitos de referencia en que se suele distribuir el panteón mítico (dioses preolímpicos, dioses olímpicos, griegos, romanos, héroes de ciclos, agrarios, etcétera).

Es en este contexto, en fin, donde hay que ubicar el abordaje que de la mitología clásica hace Cecilia Böhl de Faber (1796-1877), quien escribe bajo el pseudónimo de Fernán Caballero, en La mitología contada a los niños e historia de los grandes hombres de la Grecia en el año $1867^{11}$, a la edad de setenta años, en una edición en la que se destaca no solo el contenido sino los pequeños grabados, que hasta en un número de cien, se insertan en sus páginas. El éxito de la obra queda suficientemente reflejado en el hecho de que fue reeditada lustros después, en 1873 y 1878 , con diversas reimpresiones hasta $1908^{12}$, y de que incluso en los años veinte del siguiente siglo conoce un nuevo paso por la imprenta, y volvería a publicarse en $1943^{13}$, tras la Guerra Civil, pues, en cierta medida, Böhl de Faber se presenta para las

${ }^{8}$ Dejando a un lado las traducciones, las propuestas didácticas concomitantes en el tiempo con la obra de Fernán Caballero se aprecian (al margen de Pérez-Zaragoza Godínez, Verdejo o De la Escosura que desglosaremos en el próximo epígrafe así como de los diccionarios mitológicos) en manuales como los de Lorente, Francisco (1847): Compendio elemental de la mitología, para la mejor inteligencia de toda especie de libros que maneja la juventud estudiosa, Madrid, Repullés; y Salazar, Manuel (1872): Compendio de Mitología para los colegios de instrucción media, París, Hachette.

${ }_{9}$ González, V. (1885): Historia de la Mitología Griega y Romana, Madrid, Calleja.

${ }^{10}$ No hemos logrado identificar a V. González más allá de que, probablemente, pertenezca al equipo de la editorial Calleja en calidad de divulgador. Él mismo parece ser el autor de La Física al alcance de los niños (Madrid, Calleja, 1893).

${ }^{11}$ Caballero, Fernán (1867): La mitología contada a los niños e historia de los grandes hombres de la Grecia. Barcelona, Bastinos e Hijos.

12 Seguimos la reimpresión de 1888, que se puede leer en http://www.cervantesvirtual.com/obra-visor-din/ la-mitologia-contada-a-los-ninos-e-historia-de-los-grandes-hombres-de-la-grecia--0/html/ff2999b4-82b1-11df-acc7002185ce6064_3.html\#I_0_[Obtenido el 3 de junio de 2016].

${ }_{13}$ Caballero, Fernán (1926; reeditado en 1943): La mitología contada a los niños e historia de los grandes hombres de la Grecia, Madrid, Apostolado de la Prensa. 
autoridades educativas franquistas como un referente pedagógico ${ }^{14}$. En realidad, los textos fueron escritos diez años antes de 1867, a lo largo de 1858 y 1859, y aparecieron publicados en su mayor parte en la revista semanal La educación pintoresca, editada en Madrid, lo cual justifica en buena parte la selección y extensión de los motivos recogidos: éstos se distribuyen en dos tandas, una relativa a figuras mitológicas y otra, de manera complementaria, a figuras históricas de procedencia griega (no romana). En este sentido, la obra queda bastante descompensada, pero es que, por motivos desconocidos, Fernán Caballero deja de publicar sus aportaciones en La educación pintoresca ${ }^{15}$, donde también habían aparecido cuentos de creación propia ${ }^{16}$. De hecho, la única diferencia entre los textos publicados en 1858 y 1867 se refiere a los grandes hombres griegos, que, en tanto en la revista culminan con Milcíades y Cimón, en la edición en libro se ven completados con personalidades literarias: Homero, Hesíodo, los trágicos, Demóstenes y Esopo, entre otros, en reseñas biográficas y culturales más cortas que las ya de por sí breves entradas que habían aparecido en la revista.

La posición de Fernán Caballero en la concepción mitológica del siglo XIX resulta singular, sobre todo en lo que concierne a la consideración de su texto como «literatura infantil» propiamente dicha y no sólo como texto escolar ${ }^{17}$. Dicha concepción se aprecia tanto en la definición que hace de mitología en el contexto de las definiciones vigentes en su época como en las alusiones que se hace a la «fábula», elemento importante en el tratamiento mitológico del siglo XIX. Y es que el abordaje que se hace del término implica la superación de la idea de «teatro genealógico» y de «repertorio alfabético» para dotarse de un sentido anfibológico: la lectura del relato mítico desde perspectivas, de un lado, religiosas y, de otro, desde la explicación racional del motivo. De esta manera, lo que queda al margen de la percepción cristiana y de la lógica empírica incumbe a la fábula.

\section{EL CUENTO COMENTADO EN LA DEFINICIÓN DE FERNÁN CABALLERO}

El carácter compuesto de la palabra «mitología» constituye un argumento presente en las definiciones que se hacen de ésta hasta finales del siglo XIX. Uno de sus componentes, el relativo a la primera parte del término, se asociará a la noción de «fábula» tal como acaba de ser considerada en el parágrafo precedente. En verdad, el movimiento ilustrado en el que nace la célebre Encyclopédie el siglo anterior ya insertaba la idea de fábula en la definición de los límites de la «mitología», pero se trata de una idea programática acerca de lo que es o no conocimiento susceptible de ser abordado en sus páginas, y la mitología lo es en virtud de

14 Valls, Fernando (1983): La enseñanza de la literatura en el franquismo, Barcelona, Bosch, 106-112.

${ }_{15}$ Caballero, Fernán (1858-1859): «Pequeño curso de mitología para los niños. Los grandes hombres de Grecia», La Educación Pintoresca, Madrid, Imprenta de Miguel Campo-Redondo, 33-81.

${ }^{16}$ Cf. Trancón Laguna, Montserrat (2000): La literatura fantástica en la prensa del romanticismo, València, Institució Alfons el Magnànim.

17 Así figura en el Fondo bibliográfico «Carmen Bravo-Villasante» del CEPLI (Universidad de Castilla-La Mancha): Martínez Soria, Carlos Julián y Sánchez García, Sandra (2000): Colección Carmen Bravo-Villasante. Catálogo Bibliográfico (Fondo Antiguo), Cuenca, Ediciones de la Universidad de Castilla-La Mancha. Cf. también Encinas Reguero, María del Carmen (2015): «Los mitos griegos en la literatura infantil y juvenil del s. XIX», Thamyris, 6 (n. s.), 87-110. 
la documentación que aporta sobre situaciones y momentos no históricos de la cultura huma$\mathrm{na}^{18}$. Lo que realmente sucede es que se está produciendo un cambio de orientación, siendo tal cambio de índole metonímica desde la noción amplia de «teatro» hacia la de «fábula» centrada únicamente en la naturaleza inverosímil del relato. El «teatro», de acuerdo con el Diccionario de Autoridades en su edición de $1739^{19}$, se define como el lugar «donde alguna cosa está expuesta a la estimación o censura universal»; y no de otra manera se entiende el título con el que Fray Benito Feijoo encabezó su obra magna: Teatro crítico universal. Por su parte, la fábula mitológica se percibe sin connotaciones peyorativas al margen de la incredibilidad de su narración y, por ese motivo, es percibida como cauce para expresar otras informaciones subliminales, de índole primordialmente moral.

Así, en el Nuevo Compendio de la Mitología, o sea, ciencia o esplicación [sic] de la fábula, para poder conocer la alegoría de las Divinidades del Gentilismo, publicado por Zaragoza Godínez en 1826, se puede leer:

La palabra Mitología, compuesta de dos griegas, significa literalmente Tratado sobre los mitos o religiones antiguas; hoy su sentido es ciencia ó conocimiento de la Fábula, entendiéndose por tal la historia de las divinidades adoradas por los pueblos hasta que el Evangelio disipó las tinieblas en que yacían.

Es decir, la fábula posee una finalidad didáctica desde el propio título de la obra. De igual forma aparece en otros autores como Verdejo de Castro y Patricio de la Escosura, en los que la palabra fábula como traducción del concepto de mito se incluye en el título, sea aplicado a las figuras o a los tiempos: Nuevo compendio de la mitología o historia de los dioses y héroes fabulosos, de $1842^{20}$, y Manual de mitología. Compendio de la historia de los dioses, héroes y más notables acontecimientos de los tiempos fabulosos de Grecia y Roma, de $1845^{21}$, respectivamente, dándose la circunstancia de que Patricio de la Escosura es amigo personal de Fernán Caballero, con quien mantiene intercambio epistolar.

Así pues, la mitología como ciencia se concibe como un corpus autónomo de conocimientos relacionados con los relatos de figuras, dioses y héroes de la antigüedad grecolatina: el sentido y la disposición en el interior de ese corpus configura su objeto, con consecuencias de todo tipo: corográficas, genealógicas, iconográficas, simbólicas, presentes en textos poéticos y en las Bellas Artes. Por su parte, la mitología como «explicación» implica, de alguna manera, la ruptura del corpus, de forma que se indaga fuera de este el sentido de los temas mitológicos, los cuales poseen, desde esta perspectiva, la condición de fábula.

No obstante lo anterior, Fernán Caballero define la mitología con un componente predominantemente religioso, referido al paganismo: «Mitología es una palabra compuesta de

\footnotetext{
18 Sub voce, tomo X, 924, 1. ${ }^{\text {a }}$ edición de 1751: https://fr.wikisource.org/wiki/Page\%3ADiderot_-_Encyclopedie_1ere_edition_tome_10.djvu/924 [Obtenido el 11 de mayo de 2016] .

19 Sub voce, tomo V, edición de 1739: http://www.rae.es/recursos/diccionarios/diccionarios-anteriores-1726-1996/diccionario-de-autoridades [Obtenido el 11 de mayo de 2016].

${ }^{20}$ Verdejo de Castro, Pablo (1842): Nuevo compendio de la mitología o historia de los dioses y héroes fabulosos, Barcelona, Manuel Sauri.

${ }^{21}$ De la Escosura, Patricio (1845): Manual de mitología. Compendio de la historia de los dioses, héroes y más notables acontecimientos de los tiempos fabulosos de Grecia y Roma, Madrid, Mellado.
} 
dos voces griegas, que expresan o creencia o religión fabulosa $»^{22}$, de forma que mitología y paganismo son prácticamente términos sinónimos, que se oponen como la superstición a la religión (de acuerdo con claves que son de raigambre clásica, pues remiten a Cicerón ${ }^{23}$ ). El equívoco radica en identificar «mito» con religión y creencia con «logos», algo únicamente salvable desde el momento en que puede ser objeto de explicación, sin la que los relatos y figuras mitológicos carecerían de interés escolar según el criterio de la escritora. Y es que, en cierta manera, la singularidad de la propuesta de Fernán Caballero radica en presentar cuentos comentados; el título de la obra lo expresa de forma nítida: «Mitología contada» $a$ los niños. La idea de «creencia», por consiguiente, se aplica a la lectura literal, previa al comentario que da sentido a la publicación de los capítulos y entradas del texto.

\section{EL CONCEPTO DE FÁBULA Y LAS EXPLICACIONES EVEMERISTAS}

El término «fábula» aparece no solo como sinónimo de religión pagana en la definición que Fernán Caballero hace de «mitología», sino que, sea como tal sustantivo empleado en un contexto mitológico, sea como adjetivo, acompañando a figuras y relatos, aparece de forma significativa a lo largo del texto. De ahí que, como indicio sintomático de la lectura que se propugna en el conjunto, sea posible efectuar un análisis específico de los pasajes en que aparece dicho lexema. Más aún, según se tendrá ocasión de comprobar, cuando su empleo aparece pautado de forma elaborada en la estructura de la obra, con interpretaciones concomitantes. Entre estas ocupan un lugar destacado las explicaciones de índole «evemerista», es decir, aquellas que, en la tradición de Evemero de Misene, interpretan en clave racional motivos extraordinarios, como son la identificación de dioses con reyes y de figuras mitológicas astronómicas y atmosféricas con, por ejemplo, astrónomos legendarios. Se trata de un tipo de hermenéutica a la que tradicionalmente recurre la apologética cristiana en su polémica contra los dioses paganos ${ }^{24}$. En el caso de Fernán Caballero, las explicaciones evemeristas se convierten en una de las pautas establecidas para comentar el cuento.

Así, el término «fábula» aparece en relación con el jerarca de los dioses grecolatinos, en su denominación latina aunque inscrito en el capítulo dedicado a deidades griegas: Júpiter, quien es definido con el sintagma «fabuloso dios» $»^{25}$. A la hora de explicar a Júpiter, se le confiere un carácter mortal, con orígenes cretenses y contemporáneo de Abraham;

${ }^{22}$ Mitología es una palabra compuesta de dos voces griegas, que expresan o creencia o religión fabulosa. Los hombres olvidados del verdadero Dios, su Criador, inventaron divinidades a su albedrío; porque en el alma que Dios crió con soplo divino, existe siempre un anhelo, una necesidad de elevarse y someterse a un poder superior, que se adora, se respeta y se invoca. Cuando el hombre ya no siente esas altas y divinas inspiraciones... compadecedle, porque ahogó su alma. La Mitología es, pues, una religión que crearon los gentiles, y de ella me propongo dar a vosotros una clara, aunque sucinta, idea [p. 25].

${ }^{23}$ En obras como De natura deorum. Cf. Cicerón, Marco Tulio (1999): Sobre la naturaleza de los dioses [Edición de Ángel Escobar], Madrid, Gredos.

${ }^{24}$ Alonso Venero, Ana (2013): «El evemerismo como motivo retórico en la literatura apologética cristiana», Ílu. Revista de Ciencias de las Religiones, 24, 91-116.

${ }_{25}$ Los eruditos piensan que entre los reyes de Creta ha habido varios con nombre de Júpiter, que pueden haber sido el origen de este fabuloso dios. El más célebre, dicen, fue contemporáneo del patriarca Abrahán. Júpiter tuvo muchos nombres, que no es necesario retener, pero que es bueno saber para poderlos recordar si se viesen escritos. 
es decir, como gobernante humano, de raíces griegas y coetáneo de figuras bíblicas que comparten con él un status semejante. Además, se enumeran diferentes nombres, entre los que predominan los de raíz latina de la propia palabra Júpiter — término etimológicamente compuesto, por otra parte- y sus derivaciones léxicas. Se trata de una tradición no tanto evemerista cuanto propia de la polémica entre paganos y cristianos de los primeros siglos, planteada, por ejemplo, en Agustín de Hipona, uno de los Padres de la Iglesia, y que llega hasta autores como Fray Benito Feijoo. El carácter «fabuloso» se aplica, por consiguiente, a la condición divina de Júpiter.

Otra mención interesante al respecto de la fábula se produce en torno a la figura de Endimión, pastor del que se enamora la divinidad de la noche. Este es identificado con un astrónomo, profesión que está en el origen de «la fábula de sus amores con la luna», en palabras de Fernán Caballero ${ }^{26}$. Lo imposible del relato (un astro que se enamora de un mortal) se plasma en el concepto de «fábula», al que se contrapone la interpretación evemerista del astrónomo, presente en textos como el Teatro de los dioses de la gentilidad de Baltasar de Vitoria citado en un epígrafe precedente.

De igual forma, Ganimedes, el copero de los dioses olímpicos y figura, por lo tanto, asociada a las aventuras de Júpiter, responde a una realidad política más prosaica que la que establece el mito: Ganimedes era hijo del rey Tros (del que procede el linaje troyano) y fue enviado a Lidia, cuyo monarca le retuvo ${ }^{27}$; el propio Tros convertiría la ausencia de su hijo en servicio a Júpiter, dignificándolo con una fábula que es, por definición, falsa. La interpretación se encuentra, entre otras obras que remiten a la Antigüedad postclásica y cristiana, en el Panléxico, Vocabulario de la Fábula, de Santos López Pelegrín, publicado en $1845^{28}$.

Por lo demás, entre las figuras monstruosas que poseen la condición de fabulosas, en la parte dedicada específicamente a Grecia Fernán Caballero considera a los Cíclopes, de los que se hace una lectura iconográfica, pues son identificados con los volcanes, cuya boca se transforma en el único ojo que caracteriza a estos gigantes, que, además, viven en grutas del interior de las montañas ${ }^{29}$.

Son éstos: Opimo, Stator, Jove, Diespiter, Denio, Lapis, Tonante, Capitolino, Olímpico y Ammón, que es el más antiguo [p. 39].

${ }^{26}$ Los que todo lo quieren explicar y hallar algún fundamento a tanto dislate, dicen que Endimión fue un famoso astrónomo que se pasaba las noches en examinar los astros, y que de ahí nació la fábula de sus amores con la Luna [p. 77].

${ }^{27}$ Hebe fue hija de Juno, y cuando su padre Júpiter la vio tan hermosa, la hizo diosa de la juventud y le confirió el honroso cargo de servir de beber a los dioses en sus festines; pero un día en que al desempeñar este cargo dio una caída desairada, Júpiter la destituyó y dio su puesto a Ganimedes, que era hijo de Tros, rey de Troya, y tan hermoso que, con el fin que desempeñase ese cargo, Júpiter, convertido en águila, lo arrebató y llevó al Olimpo. Lo que ha dado pábulo a esta fábula es que Tros mandó a su hijo con otros troyanos a ofrecer un sacrificio a Júpiter en Lidia. El rey de aquel país, creyendo que eran espías los prendió, obligando al príncipe a servirle de beber en sus festines [p. 81].

${ }^{28}$ López Pelegrín, Santos (1845): Panléxico, Vocabulario de la Fábula, Madrid, Boix.

${ }^{29}$ Los Cíclopes eran terribles gigantes, hijos del Cielo y de la Tierra, que no tenían más que un ojo en medio de la frente. Júpiter los precipitó en el Tártaro; pero luego por empeño de su madre los puso en libertad. Eran hábiles herreros y fabricaron para Plutón un casco que lo hacía invencible; para Neptuno su tridente, con el que agita o calma las olas del mar, y para Júpiter sus rayos. Los tres principales Cíclopes eran Brontes, Steropes y Polifemo. 
En la exposición de Fernán Caballero se da a continuación un logrado paso desde la distribución entre mitología griega, o clásica en general, y la singularmente romana. Este paso de Grecia a Roma se efectúa a través de la figura mitológica de los Lares, que establecen responsión estructural con lo considerado en torno a Júpiter y Ganimedes. En el presente caso la fábula se refiere a los amores de Júpiter con Yuturna, una muchacha latina que se arrojó al río Tíber para escapar del dios y fue convertida luego por Juno, esposa de Júpiter, en fuente. El relato cuenta con la participación de una náyade que traiciona a Yuturna contando a Juno la traición matrimonial que pretendía Júpiter. Se trata de Lara, de quien proceden los dioses Lares. Ésta, tras ser castigada por Júpiter y condenada al infierno, obtuvo la compasión de Mercurio — protagonista en realidad del texto de Fernán Caballero ${ }^{30}$ — , quien seducido por su belleza, engendraría en ella a los Lares, según los versos de Ovidio, que convierte su leyenda en latina en virtud de su asociación fonética del nombre de la náyade con el de los dioses Lares. Según Fernán Caballero, «Estos pequeños dioses, Lares y Penates, es de lo más bonito que contiene el cúmulo de invenciones sin alma y sin corazón que constituyen la fábula» ${ }^{31}$. No expone la autora el motivo de esta afirmación, y cabe inferir que, acaso, se deba a ser hijos de quien denuncia una bajeza moral y es castigado por su valentía a este respecto.

De igual forma, en paralelo a Endimión se propone la figura de Eolo ${ }^{32}$, como viento singular latino, sea por sus orígenes italianos, de acuerdo con algunas versiones, sea por ser un rey siracusano que desde su isla adoctrinó sobre la navegación a sus súbditos, según el también siciliano Diodoro. El caso es que interviene en la Odisea y, por influencia de esta, en la Eneida, lo cual confirma su, entre comillas, latinidad, por ser Sicilia una isla colindante con la Península Itálica. Para Fernán Caballero tanto Sicilia como el hecho de

Apolo, para vengar la muerte de su hijo Esculapio, causada por los rayos que habían confeccionado, los mató a todos. Autores modernos han creído que estos Cíclopes fabulosos tenían por origen los volcanes [p. 82-83].

${ }^{30}$ Este dios aparece muchas veces mezclado en los acontecimientos de la fábula; pero su historia propia no tiene muchos lances. Siempre ocupado en los asuntos de su padre, a esto debió su enlace con la bonita náyade Lara. Fue el caso que Júpiter, al que como se complacían los griegos en suponerle siempre en aventuras amorosas, pretendió a Yuturna, hija de Dáceno, que era muy hermosa. Yuturna, asustada de los requiebros del empalagoso galán, huyó y se tiró al río Tíber, suplicando a sus náyades ${ }^{8}$ que la ocultasen, a lo que accedieron gustosas, y una de ellas, llamada Lara, indignada, participó a Juno lo que pasaba, y ésta convirtió a Yuturna en fuente. Pero Júpiter, irritado contra Lara, la mandó cortar la lengua, y a Mercurio que la llevase al infierno. Mercurio, conmovido de su desgracia y seducido por su belleza, se enlazó con ella. Tuvieron por hijos a los dioses Lares. Esta voz, que significa jefe o conductor, se les dio por distintivo, porque eran los buenos genios de las casas y custodios de las familias, como lo eran también los Penates. Como tales dioses tutelares fueron primitivamente adorados los antepasados de las familias; pero más adelante se les dio, como se ha visto, su propio ser. Eran los Lares unas estatuas pequeñitas, que se guardaban con gran veneración en el lugar más solo y secreto de la casa, denominadas «Lararia» $y$ «Penetralia» [p. 87-88].

31 Op. cit., p. 89.

${ }^{32}$ Eolo dios de los vientos, hijo de Júpiter y de la ninfa Melanipa, residía en las islas Eólidas. Allí tenía a los vientos encerrados en profundas cavernas. Cuando Ulises y sus compañeros llegaron a aquellas islas, Eolo los recibió bien y agasajó, y cuando aquél se volvió a embarcar le regaló unos pellejos en que encerró los vientos que eran contrarios a su rumbo para que no le molestasen. Sus compañeros por una necia curiosidad abrieron aquellos pellejos, para ver lo que contenían; escapáronse entonces los vientos levantando tal tempestad que perecieron en ella once de sus buques, salvándose sólo aquel en que iba Ulises, que arribó a la isla de Aea. El origen de esta fábula parece ser el que Eolo fue un príncipe que estudió con provecho la astronomía y por sus observaciones astronómicas predecía el tiempo bonancible y el tormentoso. La versión supersticiosa es más bonita; pero trato, niños míos, de ilustrar vuestra razón y no de divertir vuestra imaginación [p. 95-96]. 
ser astrónomo basta para explicar su mito, dejando a un lado la «versión supersticiosa»; la primera se orienta a la razón, la segunda a la imaginación, cuando realmente es el rey de las islas Eolias custode de los vientos del mar, a las que, de acuerdo con alguna de las leyendas, concede su nombre.

En correspondencia con los cíclopes y los volcanes, la Quimera se ubica en una montaña cuya cúspide es también un volcán y en cuyas laderas habitaban fieras que se asocian con tantos otros monstruos, entre otros, leones quiméricos ${ }^{33}$. A este mismo respecto, en el catálogo de seres monstruosos se cuentan el Can Cerbero, identificado con los perros que custodian las minas ${ }^{34}$; los hipogrifos, mitad caballo y mitad águila, que deben su carácter híbrido a un motivo antropológico en la introducción de los equinos en la civilización humana, pues, al igual que el centauro es un hombre a caballo, el caballo veloz en su carrera se convierte en hipogrifo $^{35}$. En fin, la secuencia se cierra con una plaga de langosta que se metaforiza en las harpías $^{36}$. Todos ellos secuenciados en buena medida en el libro sexto de la Eneida virgiliana, aunque no son propiamente latinos.

De alguna manera, la clausura de las alusiones a lo fabuloso en la Mitología contada a los niños culmina con una figura singular, por cuanto defiende programáticamente el propio texto. Se trata de Momo, cuyos orígenes como hijo de la Noche y el Sueño sirven a Fernán Caballero para asimilarlos con la oscuridad y el descanso, de donde nacen, paradójicamente, la risa y el juego infantiles ${ }^{37}$. No explica tal paradoja la escritora, salvo que, de forma subyacente, se promueva la transformación de los terrores nocturnos en motivos de diversión; o, en otras palabras, los crudos relatos míticos en cuentos, como, en buena medida, se sintetiza a lo largo de la obra.

\footnotetext{
${ }^{33}$ Era un monstruo que tenía la cabeza de león, el cuerpo de cabra y la cola de dragón, y que echaba fuego y llamas por la boca. Era hija de Tifón y de Echidna. El primero era un tremendo gigante con cien cabezas, que creó Juno de los males vapores de la tierra por despecho, cuando su marido Júpiter creó a Palas, a quien como sabéis hizo salir armada de su cabeza. Tuvo por mujer a Echidna, que tenía el busto de mujer y lo demás del cuerpo de serpiente. Tuvieron por hijos, además de la Quimera, el can Cerbero, la Hidra de Lerna, la Esfinge y el León de Nemea. Belerofonte combatió este monstruo y lo mató. Lo que ha dado lugar a esta absurda fábula, fue una montaña llamada Quimerífera, que coronaba un volcán, alrededor del cual vagaban leones, en cuya falda pastaban cabras y a cuyo pie se criaban serpientes; montaña que desmontó y pobló Belerofonte [p. 99-100].

${ }^{34}$ Era un mastín feroz con tres cabezas, que estaba encadenado en la orilla del Estigio, para guardar las puertas del infierno y las del palacio de Plutón. El famoso Hércules lo venció y encadenó, arrastrándole hasta un precipicio, en el que lo tiró. Las plantas sobre las que cayó la baba del enfurecido animal, se volvieron todas venenosas. La fábula del can Cerbero debe su origen a enormes mastines que los mineros tenían en sus minas para guardarlas [p. 101-102].

35 Animal fabuloso, medio caballo medio águila, que según los poetas era montado por los héroes, sin duda para significar que se servían de poderosos, ágiles y briosos caballos [p. 103].

${ }^{36}$ Eran tres, Alope, Acheloe y Ocitea, e hijas de Neptuno y de la mar. Sus cuerpos eran de milano, sus caras de viejas, con pico encorvado. Eran tan malas y voraces, que todo lo asolaban, y por doquier pasaban dejaban tras si el hambre y la desolación, por lo cual Bóreas, que es el viento norte, las persiguió hasta el mar Jónico, en el que, cansadas de volar, cayeron y se ahogaron. Dícese que lo que ha dado lugar a esta fábula fue una plaga de langosta que asoló el país [p. 104].

37 Para concluir la reseña que en estos dieciocho capítulos os he dado de los dioses fabulosos de la mitología griega, nos resta uno que hemos dejado para el último, con el fin de que os quede más fresca en la memoria su recuerdo. Es este Momo, hijo de la Noche y del Sueño, y que es, a pesar de tan oscuros y sosegados padres, el dios de la risa y de los juegos. Séaos, niños míos, este dios siempre propicio [p. 111-112].
} 


\section{EL CONCEPTO DE MITO Y LOS RELATOS DE PERSONAJES HISTÓRICOS}

Según hemos establecido, la «Mitología contada a los niños» se complementa con una «Historia de los grandes hombres de Grecia», en una serie de relatos biográficos en los que se hace presente también la idea de «fábula» conforme emplea este concepto la mitología decimonónica, pero que resulta llamativo aplicado a personalidades históricas y literarias. El paso de la mitología a la Historia no se hace de forma brusca: Fernán Caballero efectúa una elaborada transición a través de las figuras heroicas, que poseen un carácter mortal frente a las divinidades abordadas hasta este momento. A este respecto, el texto se abre con Hércules, aunque termina prevaleciendo fundamentalmente el ciclo troyano. De ahí el interés con el que aborda las figuras de Agamenón, que comanda las tropas griegas que asedian Troya, de Orestes, y, sobre todo, de Electra — hija de Agamenón y hermana de Orestes—y el anónimo esposo con el que ésta contrajo un falso matrimonio. Pues bien, el respeto que tuvo el desconocido labrador por Electra le hace digno de mención por parte de Fernán Caballero, como si de una figura cristiana se tratase en el interior de la fábula ${ }^{38}$.

Los capítulos abarcan, pues, desde Orestes a Heródoto; del primero acabamos de señalar su condición de hermano de Electra; del segundo sobresale su condición de padre de la Historia, es decir, en principio, en las antípodas de la leyenda. De esta manera, se puede decir que desde la fábula se pasa a la Historia, como si fuera un ente bifronte, tal como lo establece Fernán Caballero. Y es que el paso se hace a través de un rey, Jano, quien «fue el rey más antiguo del Lacio de que hacen mención la fábula y la Historia» ${ }^{39}$. La fábula se refiere a su carácter legendario ${ }^{40}$; la Historia, a su condición de rey del Lacio.

Otra figura histórica destacada para Fernán Caballero desde la perspectiva de la fábula es el filósofo Sócrates, quien fue condenado a muerte por reírse de los dioses mitológicos

38 Orestes reinó entonces pacíficamente en Argos, y casó con Hermíone, hija de su tío Menelao y de la bella Elena su mujer. Casó también a Pílades con una de sus hermanas, llamada Electra. Ésta había sido forzada por su madre y por Egisto, su amante, a casarse con un hombre oscuro, pero tan honrado, que hizo un casamiento fingido con tal de proteger y amparar a la perseguida princesa, que devolvió con respeto a su hermano Orestes tan luego como volvió a subir al trono, y os refiero este hecho, niños míos, porque si bien en la fábula y en la historia griega abundan hechos heroicos, son muy escasos los generosos y delicados, como es consiguiente en almas e imaginaciones que carecen de la alta y noble cultura del Cristianismo [p. 139-140].

${ }_{39}$ Fue el rey más antiguo del Lacio de que hacen mención la fábula y la Historia. Era hijo de Urano o del Cielo y de Hécate, si bien otros dicen que nació en Atenas y que cuando fue hombre equipó una flota con la cual se dirigió a Italia, donde hizo varias conquistas y edificó una ciudad que llamó de su nombre Janícula. Suponen algunos que, durante su reinado en el Lacio, Saturno expulsado del cielo se refugió en sus dominios. Fue tal la buena acogida que Jano dio a Saturno, que agradecido éste, le dotó con el doble conocimiento de lo pasado y lo futuro. Por esto se representa a aquel rey con dos rostros, el anterior para indicar que conoce todo lo que ha de venir, y el posterior todo lo que ha sucedido. Se le pinta, además, teniendo una llave en una mano y un bastón en la otra, significando lo primero que abre la puerta del año, razón por la que le consagraban el mes de enero, que llamaban «Januarius», y lo segundo que preside en los caminos. Comenzaban los antiguos romanos sus ceremonias religiosas invocando a Jano, porque estaban en la creencia que presidia a todas las puertas, a todas las entradas y que no se podía llegar sin él hasta donde están los demás dioses [p. 160-161; a continuación se sintetiza el conocido motivo relativo a las Puertas de la Guerra custodiadas por este dios.].

${ }^{40}$ Sub voce: Grimal, Pierre (1998): Diccionario de la Mitología Griega y Romana, Barcelona, Paidós, 295-296. 
para postular una religión basada en un solo dios verdadero, pues lo demás incumbe a la fábula ${ }^{41}$.

De Heródoto, en fin, se critica que no haya omitido contenidos fabulosos; de ahí que, además de padre de la Historia, se le presente de igual manera como padre de la ficción en prosa ${ }^{42}$.

De forma sutil, Ferrán Caballero incluye a Esopo, posterior a Hesíodo, autor de fábulas de animales y primer mitógrafo, en este repertorio de índole mitológica ${ }^{43}$. Culmina así con Esopo la relación del mito con la fábula. Es más, en el texto de Fernán Caballero, la integración de Esopo en el listado de figuras ilustres se hace a través del mismo Sócrates, encarcelado; de Platón, que detestaba a los poetas, pero consideraba su preceptor a Esopo; y, finalmente, de Planudes, en virtud de su condición de monje cristiano que recopiló sus fábulas ${ }^{44}$. Esopo se presenta, por consiguiente, como encarnación de la fábula aceptable, no de la mitológica.

De esta manera, desde los personajes literarios hasta los escritores Fernán Caballero traza una elaborada doctrina en torno al concepto de fábula y su imbricación en las fuentes históricas, aquellas que habrían de explicar las leyendas. Finalmente, el papel de Momo en la mitología lo ocupa Esopo en lo relativo a las personalidades célebres del mundo helénico.

\section{CONCLUSIÓN: UTILIDAD DIDÁCTICA DE LOS MITOS CONTADOS A LOS NIÑOS COMO LITERATURA INFANTIL}

A través de sus entregas, Fernán Caballero establece una síntesis mitológica original a pesar de que en el detalle no aporta nada de su propia cosecha. Hasta tal punto su síntesis es

${ }^{41}$ Sócrates era un hombre tan superior, que reconoció los dislates y falsedad de la Mitología, y sin la revelación comprendió que no había ni podía haber sino un solo Dios verdadero, criador de cielos y tierra, y se burló de los ridículos dioses de la fábula; esto fue la causa de su muerte [p. 179]

${ }^{42}$ Hase dicho que es Heródoto, como historiador, lo que Homero como poeta y Demóstenes como orador. Dicen los eruditos que su estilo es suave, noble y ameno; pero que los hechos que refiere, ni son siempre ciertos ni acertadamente escogidos; refiere cosas, añaden, que aunque no afirma, debería haber omitido por fabulosas; así es que se ha dicho de él que, si es padre de la historia, lo es igualmente de la ficción [p. 209].

43 Vid. pasaje infra, en nota 43.

${ }^{44}$ Es el fabulista más antiguo, después de Hesíodo, que inventó las fábulas. Nació en Amorium, pueblecito de Frigia. Fue esclavo de dos filósofos, Xanto e Idmo, este último lo emancipó. Los filósofos de la Grecia se habían hecho célebres por sus graves sentencias y lenguaje altisonante. Esopo tomó un método más llano y más sencillo: hizo hablar a los animales y cosas inanimadas para dar lecciones a los hombres. La fama de su saber se extendió en breve por toda la Grecia. Creso, rey de Lidia, lo hizo venir a su corte y lo colmó de beneficios. Esopo se ausentaba a veces de Lidia para viajar. Llegó a Atenas a tiempo que la avasallaba el tirano Pesistrato, y al ver lo mal que llevaban los atenienses aquel yugo, les compuso la fábula de las ranas, descontentas de todo gobierno. Viajó por Egipto y Persia, esparciendo por todas partes sus festivas lecciones de moral. A su vuelta a la corte de Creso lo envió este soberano a Delfos para hacer un sacrificio a Apolo; desagradó a aquellos habitantes, a causa de la fábula que les compuso de los leños flotantes sobre el agua, que de lejos parecen algo y de cerca no son nada, y fue tanto su encono, que lo mataron arrojándole de una alta roca. Toda la Grecia sintió su muerte, y en Atenas le levantaron una estatua. Refiérese la hermosa respuesta que dio a Chilón uno de los sabios de Grecia que le preguntaba en qué se ocupaba Júpiter. «En rebajar las casas altas y en levantar las pequeñas», respondió Esopo. Sócrates puso algunas de sus fábulas en verso, estando encarcelado; el severo Platón que consideraba los poetas como corruptores de la Humanidad, llamaba a Esopo su preceptor. Se debe a un monje griego, Planudes, la recopilación y conservación de las fábulas del insigne moralista [p.223-225]. 
elaborada que sus textos pueden tener la consideración de «literatura infantil». Y es que la escritora es capaz de resumir en pocas pinceladas el relieve de las figuras que aborda, su ubicación en el panteón clásico y la Historia Antigua y, finalmente, su interpretación dentro de la lógica evemerista o de las claves morales cristianas. El uso anfibológico del término «fábula», como narración inverosímil y como género didáctico, le permite ubicar a personajes y relatos en un entorno pedagógico en el que su presencia se explica por las consecuencias morales que es posible extraer de tales figuras y narraciones concebidas como cuentos comentados, es decir, de «literatura infantil», de la que se convierte en intérprete al tiempo que divulgadora.

No se trata, por consiguiente, de ofrecer un manual escolar con todas las prevenciones religiosas que se quiera ${ }^{45}$, sino de un compendio de textos destinados a los más pequeños, como una especie de vademécum o prontuario infantil con el que los maestros, tutores y padres pueden hacer frente a las preguntas de un niño al respecto de las personalidades y los hechos de la mitología clásica.

De forma perspicazmente estructurada, se suceden los ejemplos como apriorísticamente griegos, latinos y de personajes históricos, con sutiles engarces y responsiones entre ellos. Así, se parte del padre del panteón clásico (Júpiter, dada la prioridad que se da al nombre latino) al que se hace corresponder, en el comienzo de las figuras latinas, a los Lares, relacionados desde perspectivas mitográficas con Júpiter. Desde un punto de vista de índole evemerista son abordados Endimión en la parte griega y Eolo en la latina como figuras de astrónomos que estudian los cuerpos estelares y la meteorología respectivamente. De igual forma, se identifica a los cíclopes con los volcanes y a la Quimera con un volcán concreto, así como a diferentes monstruos con cualidades de animales: la velocidad en los caballos o los mastines como guardianes de las minas. Tales monstruos parecen acumularse en la parte latina por influencia de los textos literarios, fundamentalmente Virgilio y Ovidio, según es habitual en los repertorios mitográficos (a partir del libro VI de la Eneida y Metamorfosis en su conjunto respectivamente).

A caballo entre el relato de ficción y el propiamente histórico se sitúa la figura de Jano. La habilidad de Fernán Caballero se descubre a la hora de utilizar a este personaje de forma polisémica como puente en varios sentidos: puente entre los mundos griego y latino, entre la leyenda e historia, en virtud de su condición de divinidad y de rey mortal, entre otras, tras hacer mención a una figura anónima (meramente un labrador) que interviene en la tradición heroica asociada a las consecuencias de la Guerra de Troya en el linaje de Agamenón. Que en el conjunto de personalidades posibles entre las figuras centrales se cuenten Sócrates, Esopo y Heródoto posee un carácter nítidamente programático. Se trata de relacionar la crítica a la mitología, los relatos de animales y la Historia propiamente dicha como marco desde el que percibir teóricamente el entorno mitológico o fabuloso. Y no sólo desde la iconografía, en positivo, y desde las objeciones que se pueden hacer desde el cristianismo, en el plato negativo de la balanza.

45 A este respecto, resulta sobresaliente la «Introducción» de Mercedes Comellas sobre la personalidad de Cecilia Böhl de Faber en la edición a su cargo de Caballero, Fernán (2010): Obras escogidas, Sevilla, Fundación José Manuel Lara. 
Bajo la exposición educativa subyace, por consiguiente, un modelo teórico que bebe de la disparidad de manuales que circulan desde el siglo XVIII y la primera mitad del siglo XIX y que postula una lectura singular para los niños, donde la risa sobresalga sobre otros aspectos dramáticos y monstruosos, y la comprensión o el comentario sobre la oscuridad de los relatos.

\section{REFERENCIAS BIBLIOGRÁFICAS}

Alonso Venero, Ana (2013): «El evemerismo como motivo retórico en la literatura apologética cristiana», Ílu. Revista de Ciencias de las Religiones, 24, 91-116.

Caballero, Fernán (1858-1859): «Pequeño curso de mitología para los niños. Los grandes hombres de Grecia», La Educación Pintoresca, Madrid, Imprenta de Miguel Campo-Redondo, 33-81.

- (1867): La mitología contada a los niños e historia de los grandes hombres de la Grecia, Barcelona, Bastinos e Hijos.

- (1926; reeditado en 1943): La mitología contada a los niños e historia de los grandes hombres de la Grecia, Madrid, Apostolado de la Prensa.

- (2010). Obras escogidas [edición a cargo de Mercedes Comellas], Sevilla, Fundación José Manuel Lara.

Calonge García, Genoveva (1992): «El Teatro de los Dioses de la Gentilidad y sus fuentes: Bartolomé Cassaneo», Cuadernos de Filología Clásica - Estudios Latinos, 3, 159-170.

Chompré, Pierre (1783): Diccionario abreviado de la fábula, para la inteligencia de los Poetas, Pinturas y Estatuas, cuyos asuntos están tomados de la Historia Poética, Madrid, Manuel de Sancha.

Closa Farrés, Josep (1983): «Humanisme Classicista i Humanisme Cristià en l'ensenyament de la mitología al llarg dels segles XVIII i XIX hispànics», Faventia, 5, 131-139.

De Vitoria, Baltasar (1646): Teatro de los dioses de la Gentilidad, Valencia, Garriz.

De Urcullu, José (1823): Catecismo de Mitología, Londres, Ackerman.

Díez González, Santos (1793): Instituciones poéticas, con un discurso preliminar en defensa de la poesía y un compendio de la historia poética o mitología, para inteligencia de lso poetas, Madrid, Benito Cano.

Dumas, Claude (1988): Les mythes et leur expression au XIXe siècle dans le monde hispanique et ibéro-américain, Lille, Presses Universitaires.

Encinas Reguero, María del Carmen (2015): «Los mitos griegos en la literatura infantil y juvenil del s. XIX», Thamyris, 6 (n.s.), 87-110.

De la Escosura, Patricio (1845): Manual de mitología. Compendio de la historia de los dioses, héroes y más notables acontecimientos de los tiempos fabulosos de Grecia y Roma, Madrid, Mellado.

GonzÁlez, V. (1885): Historia de la Mitología Griega y Romana, Madrid, Calleja.

GonZÁlez GonzÁlez, Marta (2013): «Aproximaciones al estudio de la Mitología en la España del XVIII y comienzos del XIX», García Jurado, Francisco, González Delgado, Ramiro y González González, Marta [Eds.] (2013): La historia de la literatura grecolatina en España: de la Ilustración al Liberalismo (1778-1850), Málaga, Analecta Malacitana / Universidad de Málaga, 211-223.

Grimal, Pierre (1998): Diccionario de la Mitología Griega y Romana, Barcelona, Paidós.

López Pelegrín, Santos (1845): Panléxico, Vocabulario de la Fábula, Madrid, Boix.

Lorente, Francisco (1847): Compendio elemental de la mitología, para la mejor inteligencia de toda especie de libros que maneja la juventud estudiosa, Madrid, Repullés.

Martínez Soria, Carlos Julían y Sánchez García, Sandra (2000): Colección Carmen Bravo-Villasante. Catálogo Bibliográfico (Fondo Antiguo), Cuenca, Ediciones de la Universidad de Castilla-La Mancha. 
Navarrete Orcera, Antonio Ramón (2002): «Manuales de Mitología en España (1507-2002)», Tempus. Revista de actualización científica sobre el mundo clásico en España, 31, 5-107.

Salazar, Manuel (1872): Compendio de Mitología para los colegios de instrucción media, París, Hachette.

Serés, Guillermo (2003): «El enciclopedismo mitológico de Baltasar de Vitoria», La Perinola, 7 , 397-417.

Trancón Laguna, Montserrat (2000): La literatura fantástica en la prensa del romanticismo, València, Institució Alfons el Magnànim.

Verdejo de Castro, Pablo (1842): Nuevo compendio de la mitología o historia de los dioses y héroes fabulosos, Barcelona, Manuel Sauri. 